\title{
Ideal Body Weight
}

National Cancer Institute

\section{Source}

National Cancer Institute. Ideal Body Weight. NCI Thesaurus. Code C117976.

A person's optimum weight as calculated by a standard methodology. 